Iran Journal of Nursing (IJN)

Vol 34, No. 129, Apr 2021: 96- 108

\title{
Prediction of Psychological Helplessness and Fault Tolerance Based on Emotional Alexithymia in Women with Breast Cancer
}

\author{
Zahra Barari Baziarkhili ${ }^{1}$, Sedigheh Ebrahimi ${ }^{2}$
}

\begin{abstract}
Background \& Aims: Cancer is a chronic disease that has been increasingly considered by researchers, and breast cancer is one of the most common cancer types in the world, accounting for $50 \%$ of deaths. In Iran, breast cancer ( 22 per 100,000) is the most common cancer among women. In addition, breast cancer affects Iranian women about a decade earlier than in western countries. Cancer-related crisis causes imbalance and disharmony in the thoughts, body, and soul, but the most common condition for the patient is alexithymia during this period. Emotions are a set of schemas based on information processing and include symbolic and non-symbolic processes and visualizations. One of the most important factors to consider in patients with breast cancer is psychological helplessness. Various studies show that people with specific diseases have lower mental health. Many of them suffer from anxiety, anger, sadness, social isolation, and depression, which together cause the person to become psychologically helpless. Another psychological variable that is associated with or can affect cancer is fault tolerance. Failure occurs when a person fails to achieve the desired goal. Failure is generally understood as a state of inhibition in satisfying the motive or interference in goal response or in the mediating action that leads to that goal. Fault tolerance refers to a person's ability to show resilience in the face of repeated failure and a hostile environment. Failure to find local and foreign researches on women with breast cancer makes it necessary to research in this area and determine whether psychological helplessness and fault tolerance can be predicted based on alexithymia in women with breast cancer.

Materials \& Methods: This cross-sectional predictive correlational study was performed on 230 women with breast cancer who were referred to the specialized surgery and cancer clinic of Dr. Mousavi Hospital in Gorgan and the comprehensive cancer center of Imam Khomeini Hospital in Sari in 2018. The instruments used to collect data included the demographic questionnaire, the Toronto Emotional Dysfunction Questionnaire, the Psychological Helplessness Questionnaire, and the Fault Tolerance Questionnaire. The data were then analyzed using Pearson correlation coefficient and stepwise regression in SPSS version 16. The confidence level was considered at $\mathrm{P}<0.01$.

Results: Regarding the alexithymia variable, $3.25 \%$ of the patients had difficulty identifying emotions and regarding the psychological helplessness variable, $7.78 \%$ of the patients had symptoms of high anxiety, and regarding fault intolerance variable, $6.17 \%$ of the patients had symptoms of intolerance of injustice. There was a direct relationship between the variables of alexithymia and the subscales of depression $(\mathrm{P}<0.003)$, anxiety
\end{abstract}

\footnotetext{
1. Department of Psychology, Islamic Azad University, Ayatollah Amoli Branch, Amol, Iran author) Tel: $09300305103 \quad$ Email: zahrabarari49@gmail.com

2. Master of Clinical Psychology, Islamic Azad University, Ayatollah Amoli Branch, Amol, Iran
}

(Corresponding 
$(\mathrm{P}<0.002)$, stress $(\mathrm{P}<0.001)$, and psychological helplessness $(\mathrm{P}<0.000)$. It can also be said that there was a direct relationship between alexithymia and subscales of intolerance of emotional failure $(\mathrm{P}<0.001)$, sadness intolerance $(\mathrm{P}<0.001)$, intolerance of failure $(\mathrm{P}<0.005)$, and intolerance of injustice $(\mathrm{P}<0.002)$. Alexithymia was also able to predict psychological helplessness $(\mathrm{P}<0.000)$, and fault tolerance $(\mathrm{P}<0.001)$.

Conclusion: The overall result of the study showed a significant direct correlation between alexithymia, psychological helplessness, and fault intolerance, in a way that an increase in alexithymia score increased depression, anxiety, and stress of women with breast cancer, and alexithymia was directly correlated with fault intolerance, meaning that with increasing alexithymia score in women with breast cancer, the ability to tolerate discomfort, injustice, and lack of progress decreased in these women. According to these results, it is necessary to teach emotion regulation strategies along with using other treatment methods to reduce stress, depression, and anxiety and increase resilience and fault tolerance of women with breast cancer.

Keywords: Alexithymia, Psychological Helplessness, Fault Tolerance, Breast Cancer

\section{Conflict of Interest: No}

How to Cite: Barari Baziarkhili Z, Brahimi S. Prediction of Psychological Helplessness and Fault Tolerance Based on Emotional Alexithymia in Women with Breast Cancer. Iran Journal of Nursing. 2021; 34(129): 96108.

Received: 18 Jan 2021

Accepted: 19 Apr 2021 


\title{
بيش بينى درماندتى روانشناختى و تحمل ناكامى بر اساس نارسايى هيجانى در زنان مبتلا به سرطان بستان
}

\author{
زهرا برارى بازيارخيلى '، صديقه ابراهيمى
}

جكک10

زمينه و هدف:. سرطان به عنوان يكى بيمارى مزمن، به طور فزايندهاى مورد توجه ئزوهشگران قرار كرفته است و از ميان همه انواع سرطانها، سرطان

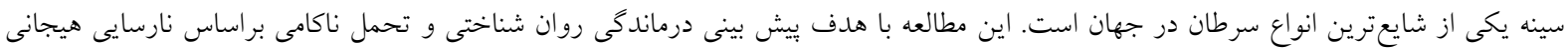
در زنان مبتلا به سرطان يُتان انجام شد.

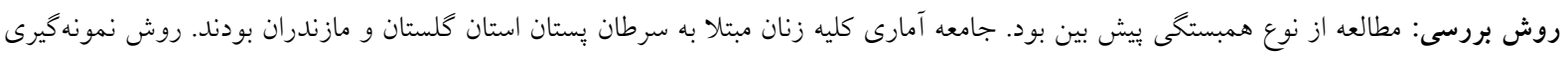

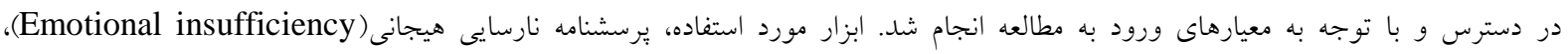

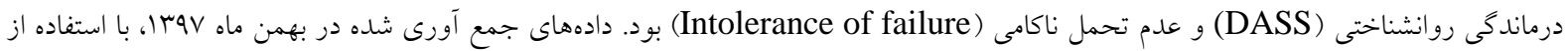

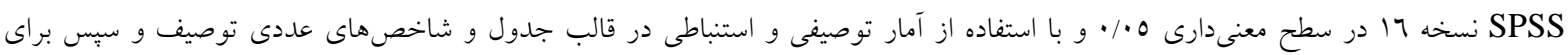

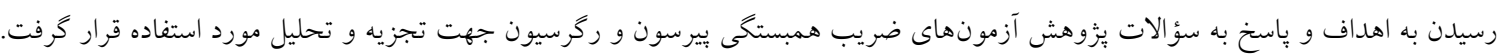

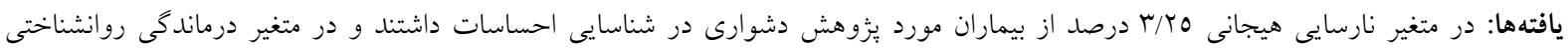

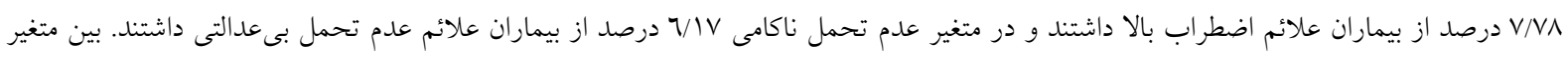

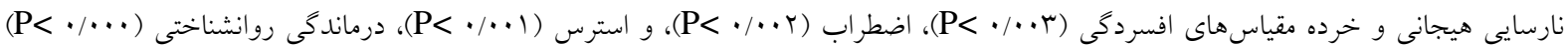

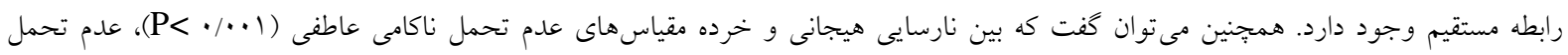

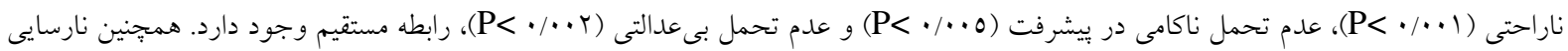

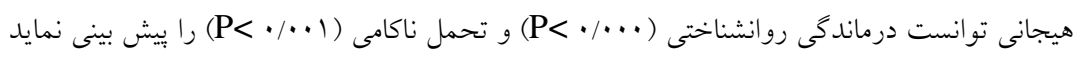

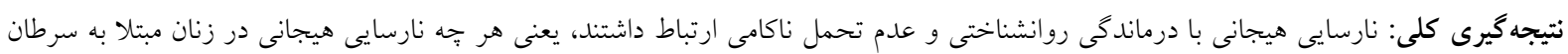
پِستان بالاتر باشد، افسردكى، استرس و اضطراب در آنها افزايش يافته و ميزان عدم تحمل ناكامى آنها افزايش مى يابد. بر اساس نتايج جهت كاهش

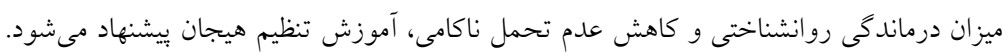

كليد وازمها: نارسايى هيجانى، درماندگى روان شناختى، تحمل ناكامى، سرطان بِتان.

تعارض منافع: وجود ندارد.

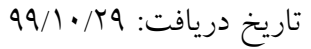

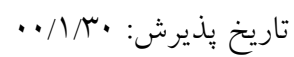

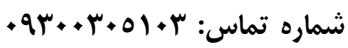

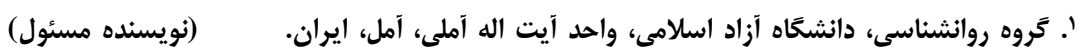

Email: zahrabarari49@gmail.com '. كارشناس ارشد روانشناسى بالينى، دانشَّاه آزاد اسلامى، واحد آيت اله آملى، آمل، ايران 
تنظيم و تعديل هيجانهاى ناراحت كننده است. اين سازه

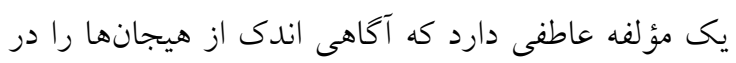

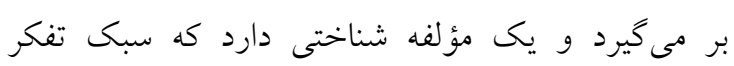

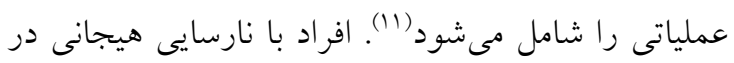

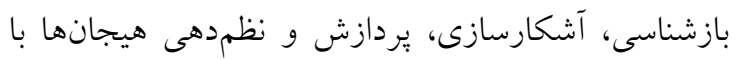

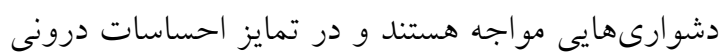

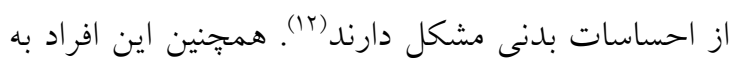

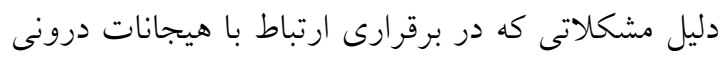

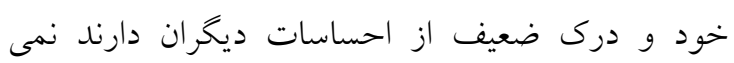
توانند روابط نزديكى با ديخران داشته و آن را حفظ كنند و به طور مناسب از حمايتهاى اجتماعى به منظور

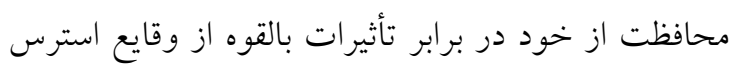

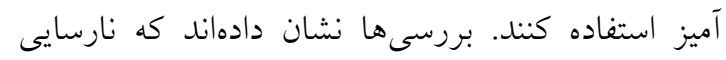

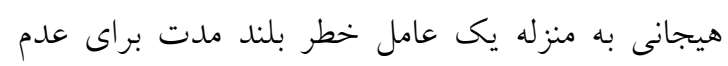

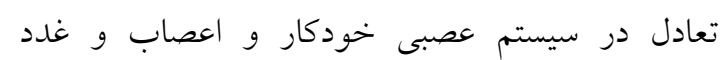
است (rا) و منجر به جلوكيرى از تنظيم موفقيت آميز

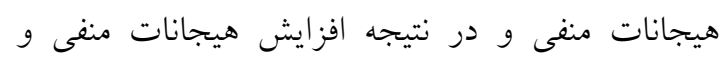
تضعيف سيستم ايمنى مىشود كه ممكن است به ايجاد و دئس

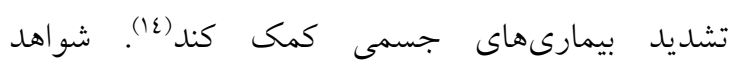

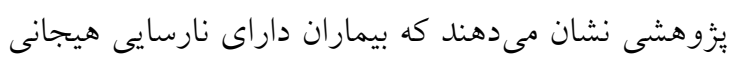

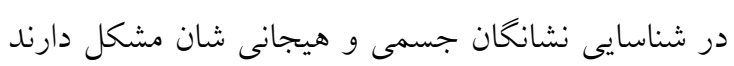

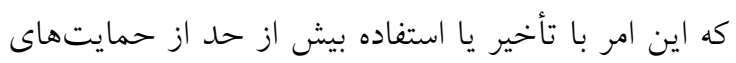

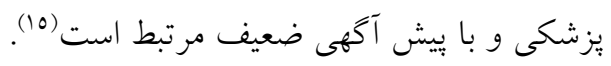

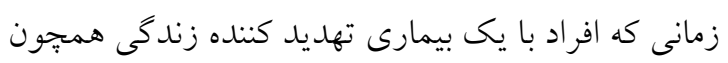

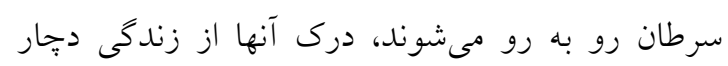

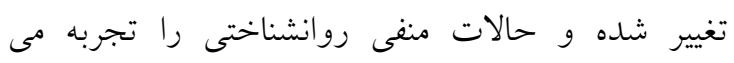

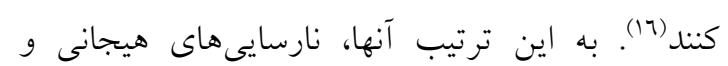

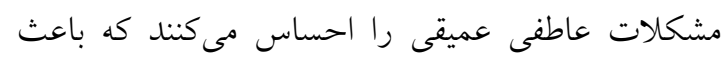

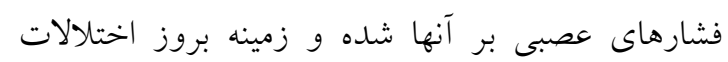

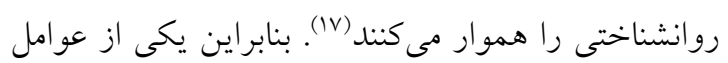

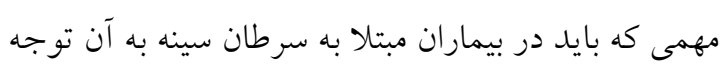

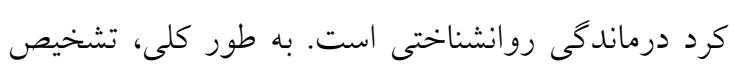

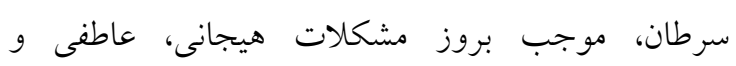
درماندكى روانشناختى عميقى در بيماران مى شود. برخى هرونى

\section{مقدمه}

سرطان به عنوان يك بيمارى مزمن، به طور فزايندهاى

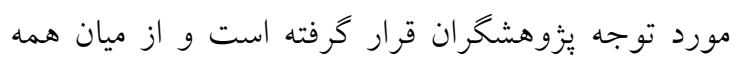
انواع سرطانها، سرطان سينه يكى از شايعترين انواع

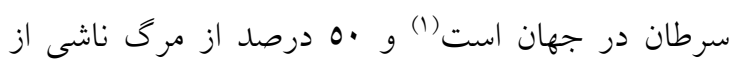
سرطان را سرطان سينه موجب مىشود(؟). در ايران

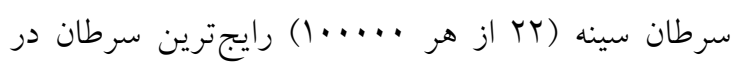
ميان زنان كزارش شده است. علاوه بر اين، سرطان سينه زنان ايرانى را حدود يكى دهه زودتر از كشورهاى غربى تحت تأثير قرار مى دهل (r). تشخيص سرطان سينه و درمان

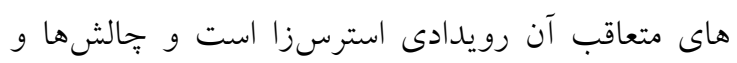
آشفتخى هاى بسيار زيادى در زنان به دنبال دارد و سرطان سينه نيز مانند هر نوع سرطان جنبههاى مختلف سلامت

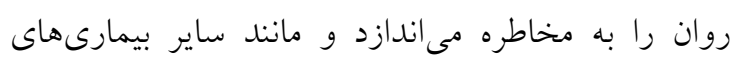

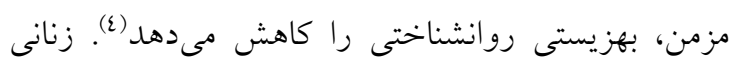
كه تحت روشهاى درمانى ماستكتومى، شيمى درمانى و يرتو درمانى قرار گرفتهاند، تنش روانى بيشترى را تحمل

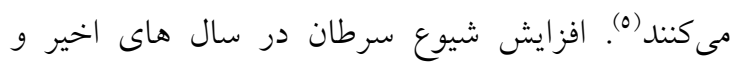
اثرات آن بر ابعاد مختلف جسمى_ــ روانى و اجتماعى إنى زندكى بشر سبب شده است كه سرطان به عنوان مشكل عمده بهداشتى قرن شناخته شود (7). اما امروزه تنها زنده ماندن بيماران مدنظر نيست، بلكه بيماران خواهان يك لهـ

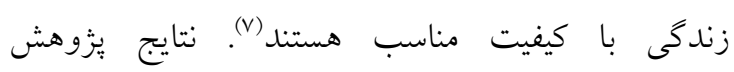

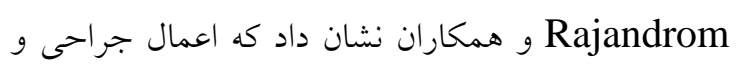
درمان فشرده طولانى مدت (مانند شيمى درمانى و راديوترايى) و عدم قطعيت در طول بيشرفت بيمارى منجر به علائمى مانند اضطراب، ترس و افسردگى مى شود (1). بحرانهاى ناشى از سرطان سبب عدم تعادل و ناهماهنكى سودى فكر، جسم و روح شود، اما بيشترين حالت در اين دوره براى بيمار نارسايى هيجانى است (9). هيجانها دستهاى از طرحوارههاى مبتنى بر بردازش اطلاعات و شامل فر آيندها

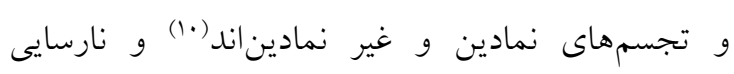
هيجانى نشان دهنده بىنظمى در عملكرد شناختى براى 
بدون اينكه به شيوههاى نايسند رفتارى دست بزند (rآ).

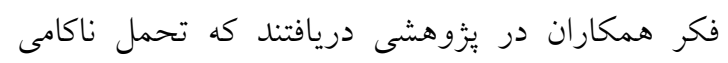

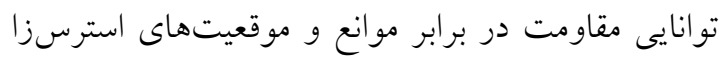

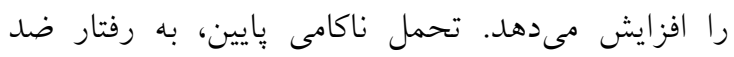

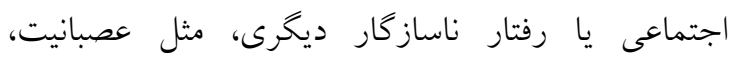

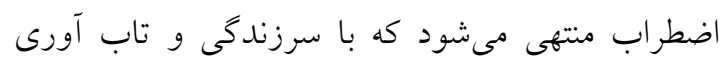

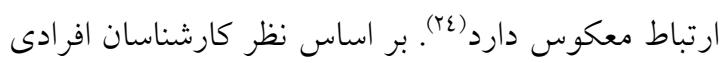
كه از درجه بالاترى از سلامت روانى برخوردارند در

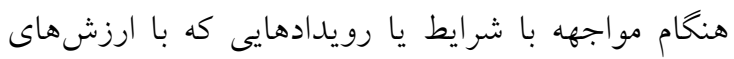
اساسى، اهداف و ترجيحاتشان در تعارض است، فلسفه

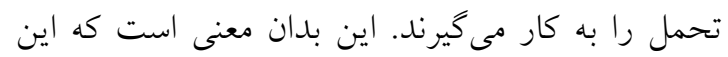

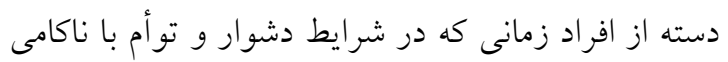

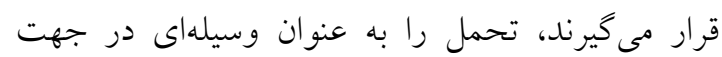

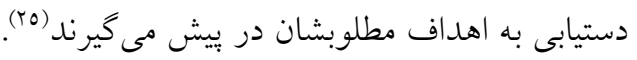

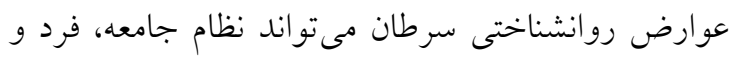

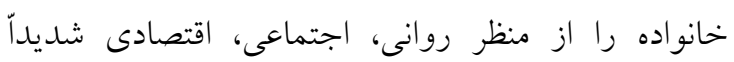

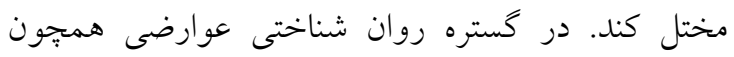

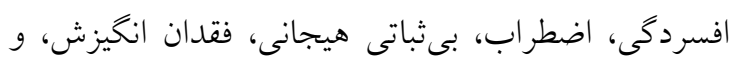

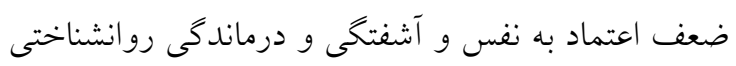

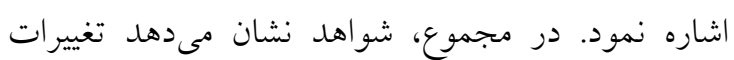

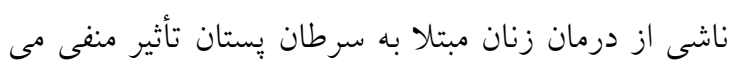
كذارند و باعث مىشوند تا اين زنان احساس كنند

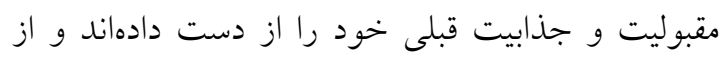

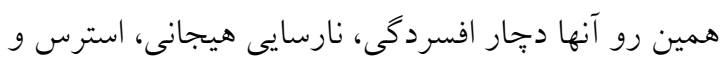

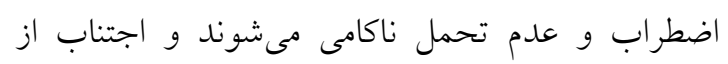

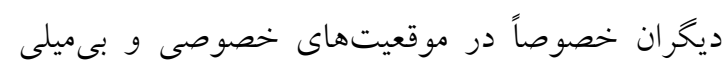

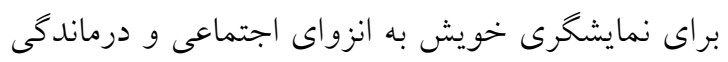

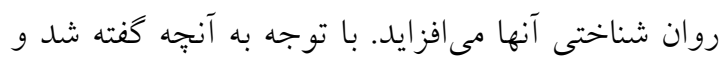

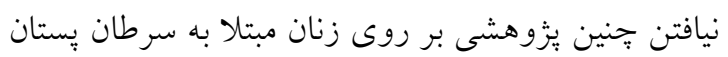

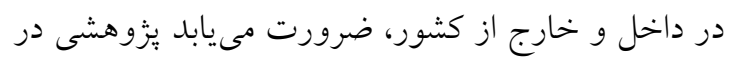

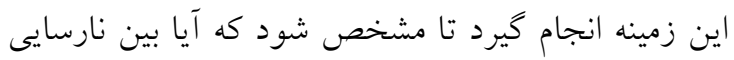

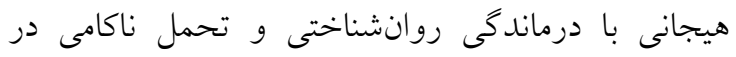

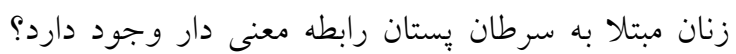

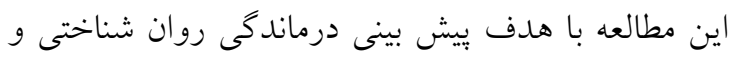

از دلايل بروز اين مشكلات، معانى ضمنى اين تشخيص در ذهن بيمار از قبيل احتمال بدشكلى بلدنى، درد،

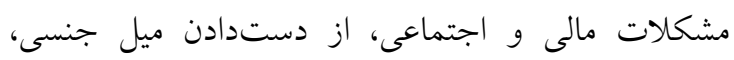
كاهش فعاليت اجتماعى، ازهم گسيختكى ساختار خانواده،

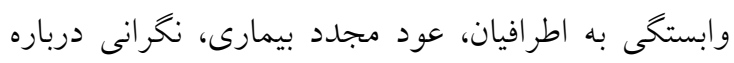

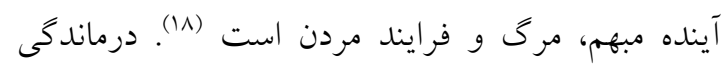

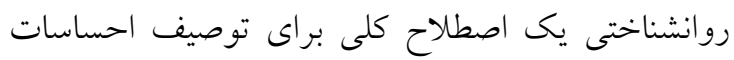

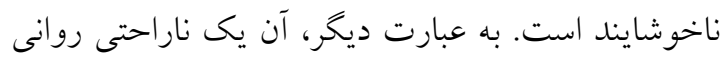
است كه با فعاليتهاى فرد با زندكى روزانه تداخل دارد.

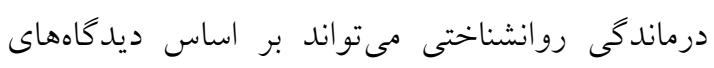

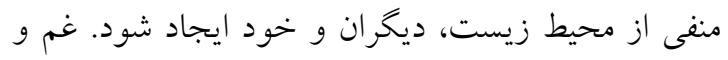
اندوه، اضطراب، حواس يرتى و نشانههاى بيمارىهاى روانى تظاهرات درماندگى روانشناختى مىباشند (19). ينج

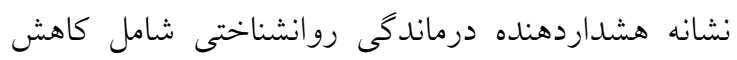

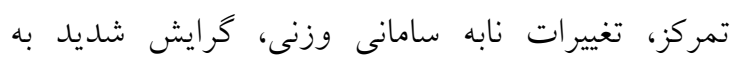

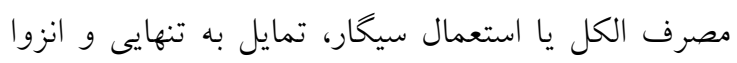

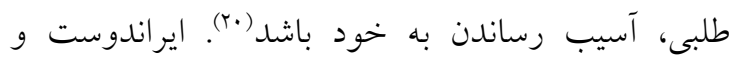

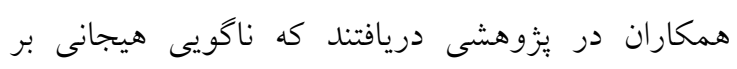

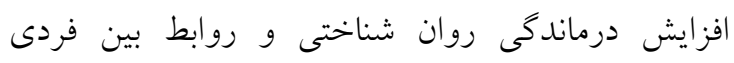
اثر كذار مىباشد (19). سرطان بر ابعاد روانشناختى تأثير كذاشته و با ايجاد درگيرى ذهنى موجب كاهش كيفيت زيست روانى افراد

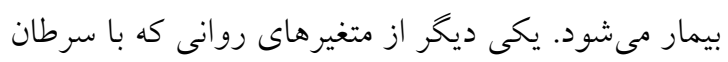

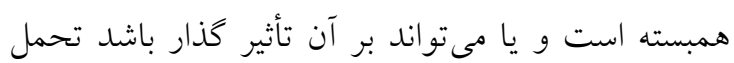

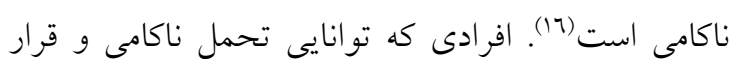

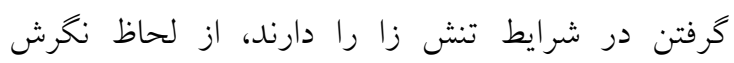

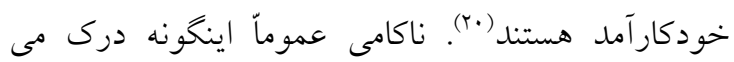

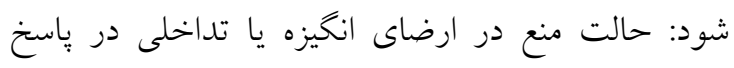

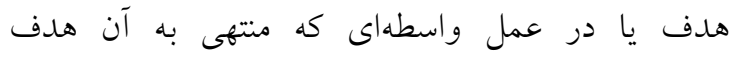

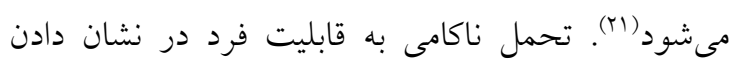

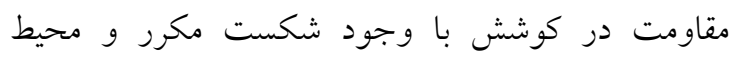

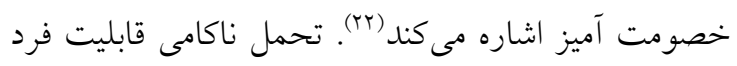
براى مقاومت در برابر ناكامى است، بدون اينكه در

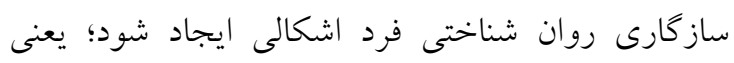


هيجانى تورنتو (Toronto emotional failure) بود كه اين برسشنامه توسط Bagbey در سال 199 ساخته

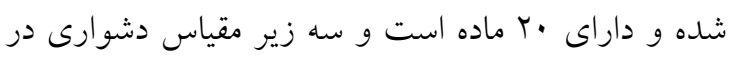

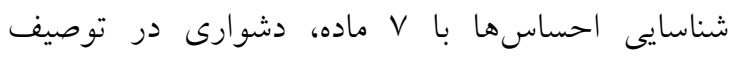
احساسها با م ماده و جهت كيرى فكرى بيرونى با م ماده

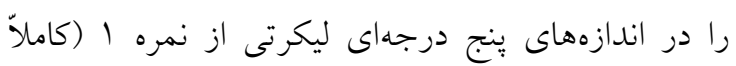

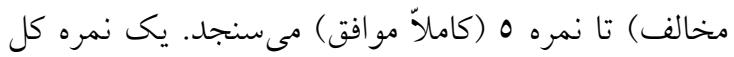
نيز از جمع نمرههاى سه زير مقياس براى نارسايى هيجان

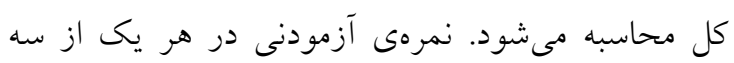

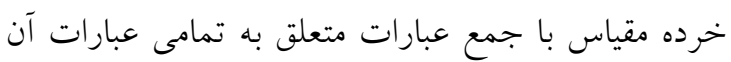

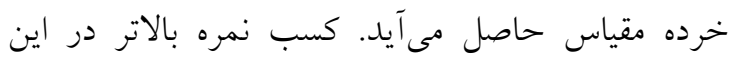

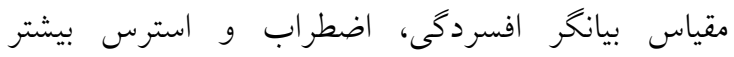
است(·). بشارت در بزوهش خوده، با استفاده از تحليل

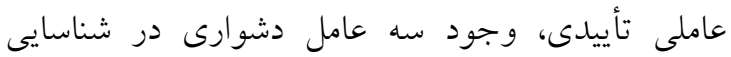
احساسها، دشوارى در توصيف احساسها و جهت

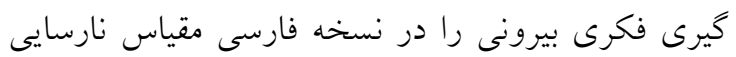

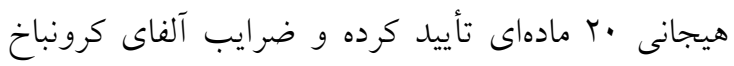

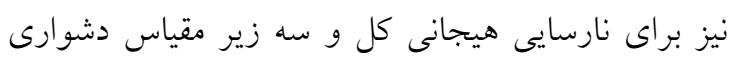

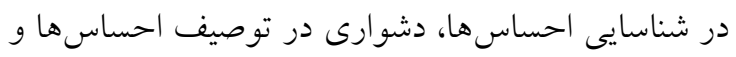

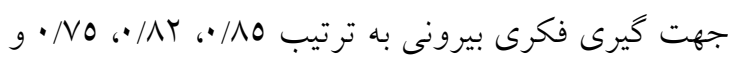

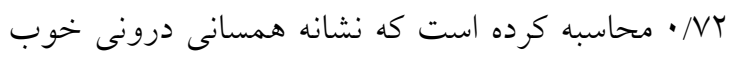

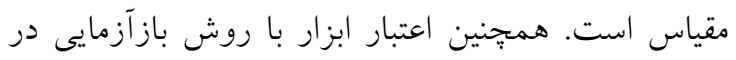
يك نمونه TV نفرى در دو نوبت با فاصله جهار هفته از rr=•/AV تاى rr=•/A.

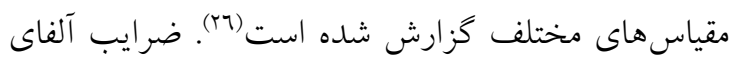
كرونباخ در اين يزوهش براى نارسايى هيجانى كل و سه

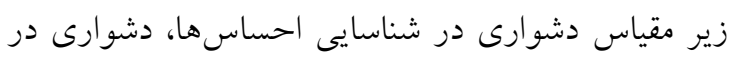
توصيف احساسها و جهت گيرى فكرى بيرونى به ترتيب

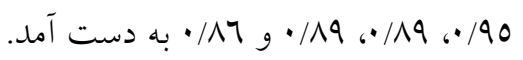
بخش سوم شامل يرسشنامه درماندكى روانشناختى

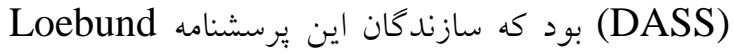
Loibund\& عرضه كردند. مقياس افسردگى، اضطراب و استرس براى

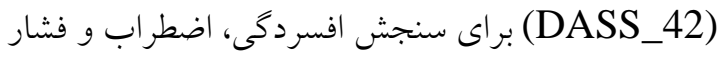

تحمل ناكامى بر اساس نارسايى هيجانى در زنان مبتلا به

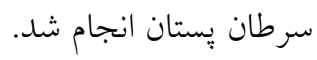

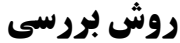

اين مطالعه مقطعى از نوع همبستخى بيش بيش بين بر روى

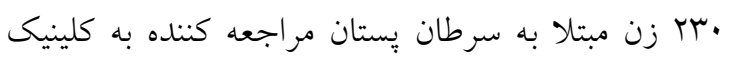
تخصصى جراحى و سرطان بيمارستان دكتر موسوى شهر كركان و مركز جامع سرطان بيمارستان امام خمينى (ره)

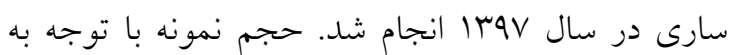

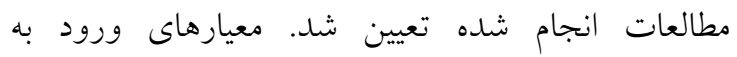
يزوهش عبارت بودند از: تشخيص سرطان پِّتان بر

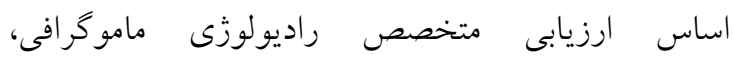

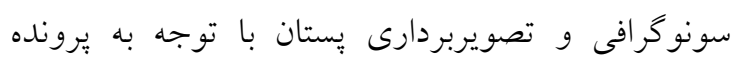

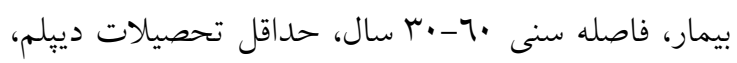

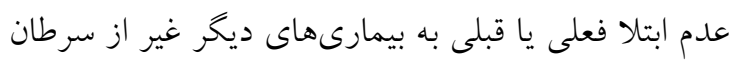

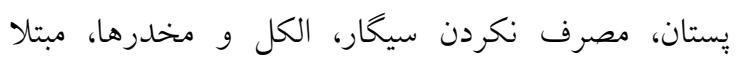
نبودن به بيمارىهاى روانى شناخته شده به اظهار خود

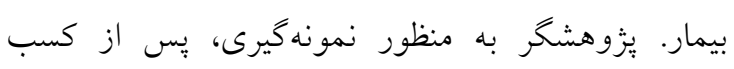

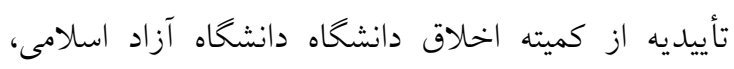

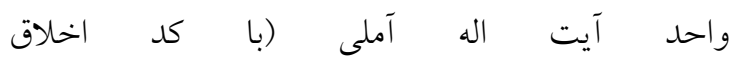
(IR.IAU.AK.REC.1397.027 و اخذ معرفى نامه

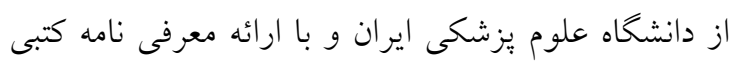
به كلينيك تخصصى جراحى و سرطان بيمارستان دكتر

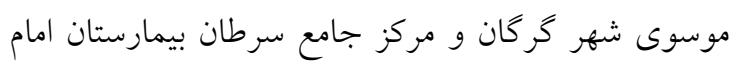

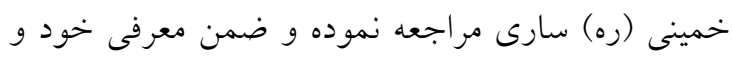
كسب اجازه از واحد تحقيقات و يزّوهش بيمارستان، اطلاعات كافى در مورد اهداف يزٔوهش و نحوه انجام كار

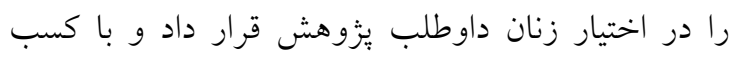
رضايت نامه كتبى آكاهانه به داوطلبان شركت در

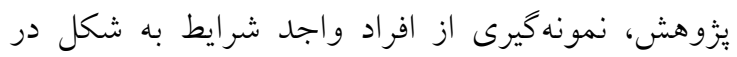
دسترس انجام شد. در بخش اول يرسشنامه مشخصات فردى شامل (سن،

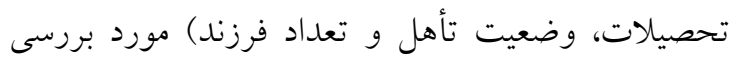

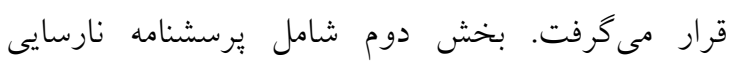


عاملى بالاتر از •ب/· دارند و ريشه خطاى ميانخين

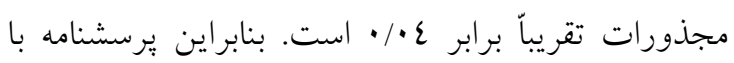
جهار عامل از برازش قابل قبولى برخوردار است.

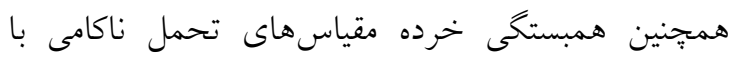

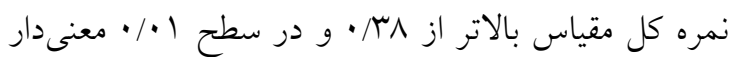

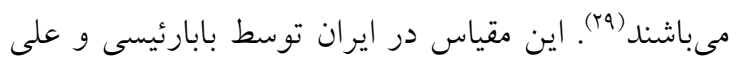

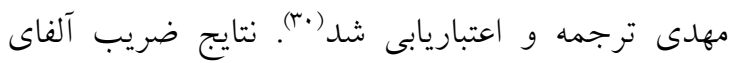

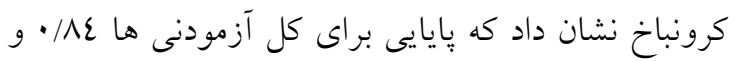

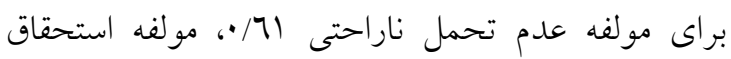

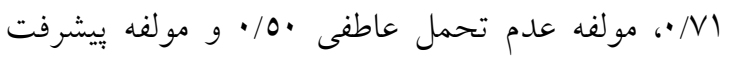

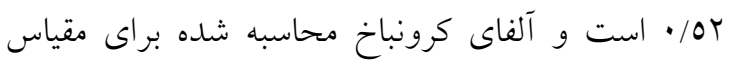

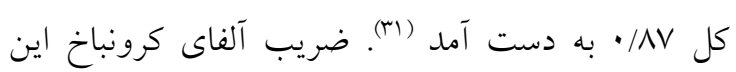

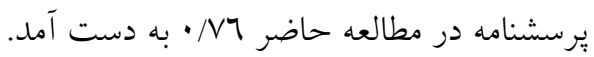

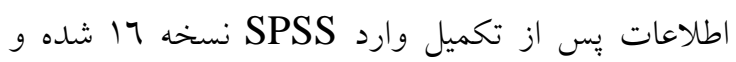

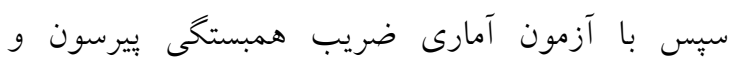
ركرسيون گام به گام مورد تجزيه و تحليل قرار كرفتند.

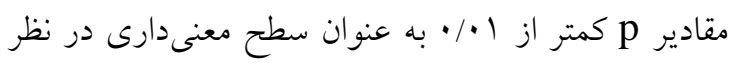
كرفته شد.

\section{يافتهها}

نتايج نشان داد كه بيشترين بيماران مورد يزوهش داراى

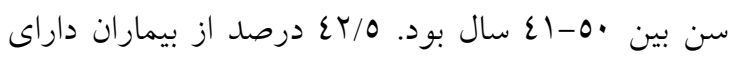
تحصيلات كارشناسى بوده و 9 9 9 درصد بيماران متأهل

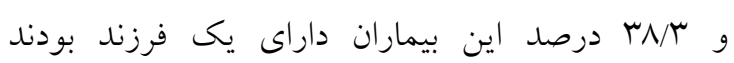

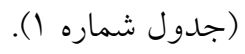

روانى طراحى شده است و در يكى طيف ليكرت ع درجه اى (1= بسيار زياد در مورد من درست است، ع= به هيج وجه در مورد من درست نيست) نمرهكذارى مىشود. اين دين

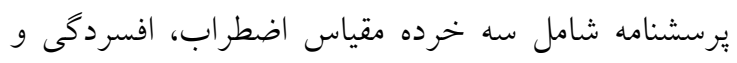

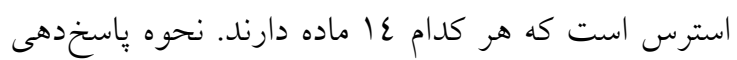

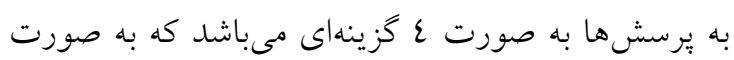

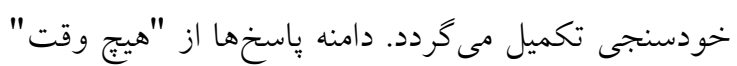
تا "هميشه" متغير است. Loibund \& Loebund

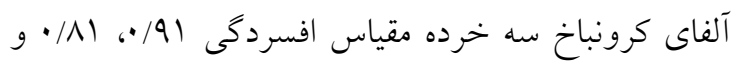
1^9/• اضطراب و استرس را به ترتيب كزارش كردهاند (IV).

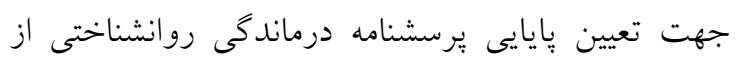

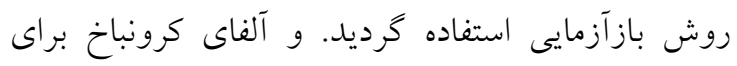

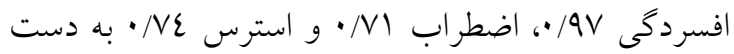

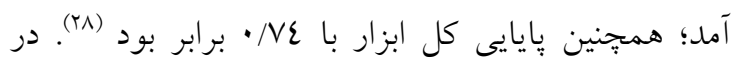

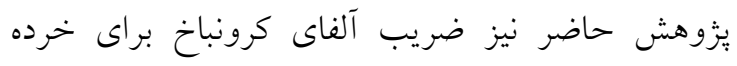

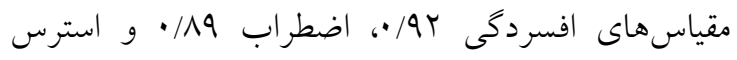

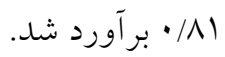

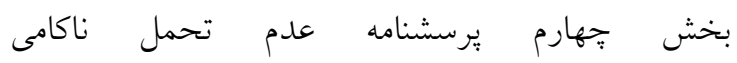

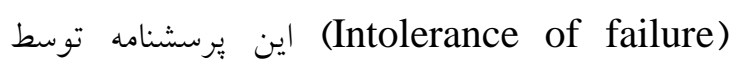
ساخته شد. يرسشنامه تحمل ناكامى داراى Harrington

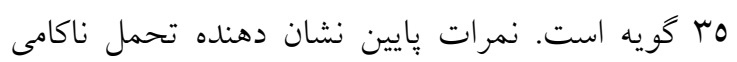

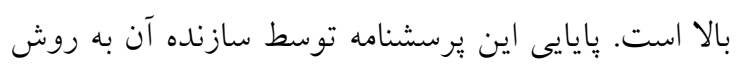

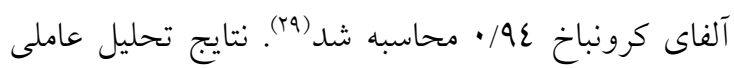
تأييدى نشان داد شاخصهاى مقياس تحمل ناكامى بر روى عوامل از قبل طراحى شده توسط سازنده آن بار

جدول شماره (: شاخصهاى فردى شركت كنندًان در مطالعه

\begin{tabular}{|c|c|c|c|}
\hline درصد & تعداد & كروه & متغير \\
\hline$r 7 / 7$ & $\pi r$ & $r \cdot-\varepsilon$. & \\
\hline$\varepsilon$. & 1.1 & $\varepsilon 1-0$. & سن \\
\hline$\Gamma r / \varepsilon$ & 97 & $01-7$. & \\
\hline$r \varepsilon / 0$ & va & دييلم & \\
\hline$\varepsilon r / 0$ & 91 & ليسانس & تحصيلات \\
\hline rI & $\varepsilon 9$ & فوق ليسانس & \\
\hline r & $\varepsilon$ & دكترى & \\
\hline $9 / 0$ & rr & مجرد & لضعيت تأهل \\
\hline
\end{tabular}




\begin{tabular}{|c|c|c|c|}
\hline $9 \cdot 10$ & $r \cdot \Lambda$ & متأهل & \\
\hline $11 / \mathrm{V}$ & TV & بدون فرزند & \\
\hline$\mu_{\Lambda / \Gamma}$ & $\Lambda$ & ا فرزند & تعداد فرزند \\
\hline$r \varepsilon / \Lambda$ & ov & ب فرزند & \\
\hline rO/T & $0 \wedge$ & " فرزند و بيشتر & \\
\hline
\end{tabular}

اضطراب بالا داشتند و در متغير عدم تحمل ناكامى V/IV درصد از بيماران علائم عدم تحمل بىعدالتى داشتند

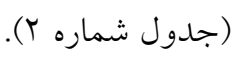

نتايج يُزوهش همجنين نشان دهنده آن بود كه در متغير

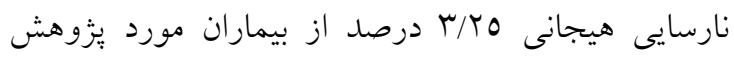
دشوارى در شناسايى احساسات داشتند و در متغير درماندگى روانشناختى V/VA درصد از بيماران علائم

جدول شماره ז: ميانكَين و انحراف معيار نمرات نارسايى هيجانى، درماندكى روانشناختى و عدم تحمل ناكامى

\begin{tabular}{|c|c|c|c|}
\hline انحر اف معيار & 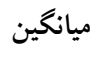 & حداقل & 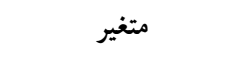 \\
\hline r/ro & $r \cdot / T V$ & دشوارى در شناسايى احساسات & \\
\hline$r / \varepsilon 7$ & $\mid V / \varepsilon V$ & دشوارى در توصيف احساسات & نارسايى هيجانى \\
\hline$T / \Sigma T$ & $T V / T \varepsilon$ & تفكر عينى & \\
\hline $0 / 1 \mathrm{~V}$ & $7 \varepsilon / 91$ & نمره كل نارسايى هيجانى & \\
\hline$V / \cdot 9$ & $\varepsilon \tau / \cdot 0$ & افسردگى & \\
\hline $\mathrm{V} / \mathrm{V} \wedge$ & rq/or & اضطراب & درماندگى روانشناختى \\
\hline $7 / 79$ & $M r / v q$ & 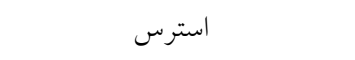 & \\
\hline$\varepsilon / 190$ & $\varepsilon V / 0 \ldots$ & نمره كل درماندگى روانشناختى & \\
\hline$\varepsilon / 01$ & $r M / 07$ & عدم تحمل عاطفى & \\
\hline$r / 9 r$ & $19 / \pi V$ & عدم تحمل ناراحتى & عدم تحمل ناكامى \\
\hline$\varepsilon / 0 r$ & $r \mu / T$ & عدم تحمل ييشرفت & \\
\hline $7 / I V$ & $\varepsilon q / \varepsilon \uparrow$ & عدم تحمل بى عدالتى & \\
\hline$\Lambda / \varepsilon$ & $\varepsilon 9 / 1\}$ & نمره كل عدم تحمل ناكامى & \\
\hline
\end{tabular}

و عدم تحمل بىعدالتى رابطه مستقيم وجود دارد، و به عبارتى با افزايش نارسايى هيجانى در زنان مبتلا بـ بـ

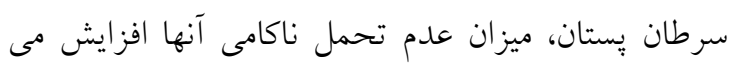
يابد. يبش از اجراى رگرسيون، مفروضهى همخطى بين متغيرهاى يزّوهش از طريق دو شاخص عامل تورم واريانس و شاخص تحمل بررسى كرديد كه ميزان آنها

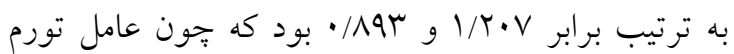
واريانس كمتر از ·ل و مقدار شاخص تحمل بيشتر از • • • بود مى توان نسبت به نبود هم خطى اطمينان حاصل كرد (جدول شماره س).
نتايج همبستخى بين متغيرهاى يزوهش نشان داد كه ارتباط بين متغيرها در سطح 1 + • معنىدار بوده، بنابراين با 99 درصد اطمينان اين نتيجه حاصل شد كه بين متغير نارسايى هيجانى و خرده مقياسهاى افسردگى، اضطراب و استرس درماندگى روانشناختى رابطه مستقيم وجود دارد، و به عبارتى با افزايش نارسايى هيجانى در زنان مبتلا به سرطان بِتان، ميزان درماندگى روانشناختى در آنان افزايش مىيابد و بالعكس. همجنين مىتوان كفت كه بين نارسايى هيجانى و خرده مقياسهاى عدم تحمل ناكامى عاطفى، عدم تحمل ناراحتى، تحمل عدم بيشرفت جدول شماره س: همبستَى بين نارسايى هيجانى با عدم تحمل نلإبامى و درماندكى روانشئاختى زنان مبتلا به سرطان يستان 


\begin{tabular}{|c|c|c|}
\hline $\mathbf{P}$ & ضريب بيرسون & متغيرها \\
\hline$\cdot \cdots r$ & **./OrI & نارسايى هيجانى - افسردگى \\
\hline 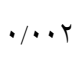 & $* * \cdot / 017$ & نارسايى هيجانى - اضطراب \\
\hline$\cdot \cdots 1$ & **. $\cdot / 7 T V$ & نارسايى هيجانى - استرس \\
\hline$\cdot \cdots 1$ & $\cdot / 71 r^{* * *}$ & نارسايى هيجانى - تحمل عاطفى \\
\hline$\cdot \cdots 1$ & $\cdot / \Lambda \Lambda^{* * * * \sigma^{*}}$ & نارسايى هيجانى - تحمل ناراحتى \\
\hline$\%$ & $\cdot / 490^{* \%}$ & نارسايى هيجانى - تحمل بيشرفت \\
\hline$\% r$ & $\cdot / T \cdot 0^{\text {**** }}$ & نارسايى هيجانى - تحمل بى عدالتى \\
\hline
\end{tabular}

درماندگى روانشناختى و س/ درصد از واريانس عدم تحمل بى عدالتى را ييش بينى مى كند (جدول شماره ع).

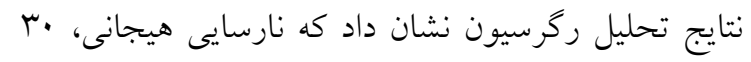

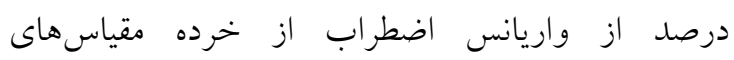

\begin{tabular}{|c|c|c|c|c|c|c|}
\hline Sig & $\mathbf{F}$ & Beta & R2 & $\mathbf{R}$ & متغير ملاكى & متغير بيش بين \\
\hline$\cdot \cdots$ & YN/YT & $1 / \varepsilon \varepsilon 0$ & - KVVY & $.10 \pi r$ & افسردكى & نارسايى هيجانى \\
\hline$\cdot / \cdot 1$ & $r q / T V$ & $1 / 0 V \varepsilon$ & $\cdot \pi \cdot 1$ & $.10 \varepsilon 9$ & اضطراب & نارسايى هيجانى \\
\hline$\cdot / \cdot 1$ & $r r / 77$ & r/09T & $\cdot / \pi \Lambda$. & .1079 & استرس & نارسايى هيجانى \\
\hline$\cdot / \cdots$ & $r / / T_{0}$ &.$/ 179$ & $\cdot / \wedge \varepsilon$ & $\cdot / 4 \wedge 9$ & عدم تحمل عاطفى & نارسايى هيجانى \\
\hline$\cdot / \cdot r$ & $r \cdot / 9$. & $\cdot / 191$ & $\cdot / \cdot v 1$ & $\cdot / 477$ & عدم تحمل ناراحتى & نارسايى هيجانى \\
\hline$\cdot / . \cdot 1$ & Tr/NI &.$/ 194$ & $\cdot / \cdot v_{0}$ &.$/$ TOV & عدم تحمل بيشرفت & نارسايى هيجانى \\
\hline$\cdot / \cdots$ & $r \mid \pi r$ & $\cdot / \backslash \wedge \vee$ &.$/ .94$ & . MOV & عدم تحمل بى عدالتى & نارسايى هيجانى \\
\hline
\end{tabular}

شهرستان بردسير نشان دادند كه بين ناگويى هيجانى و

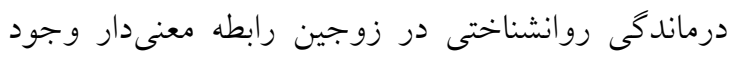

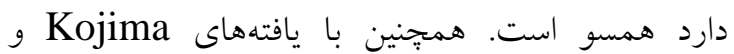
همكاران(عا) در بين كارگران زاينى كه بيان نمودند نارسايى هيجانى با تضعيف سيستم ايمنى به ايجاد و

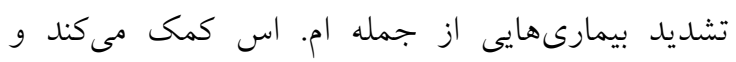

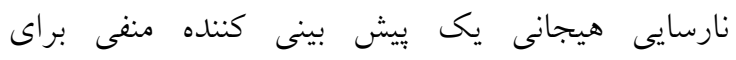

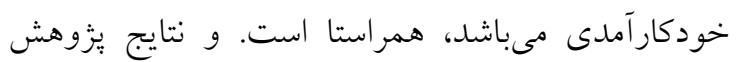

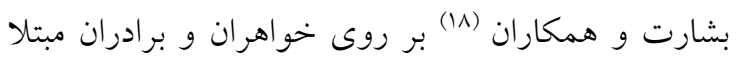

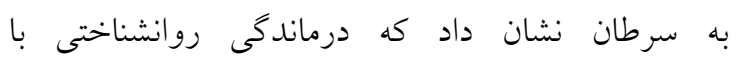

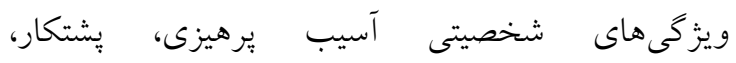

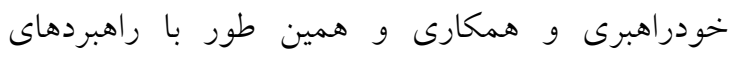
نظمجويى شناختى هيجان رابطه دارند. در تبيين اين نتايج

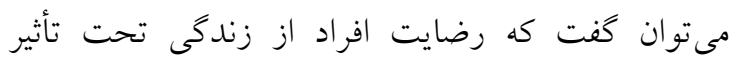

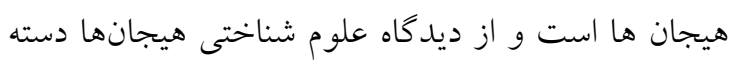

\section{بحث و نتيجه كيرى} همانطور كه نتايج نشان داد نارسايى هيجانى، درماندى دئى

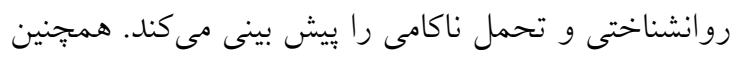

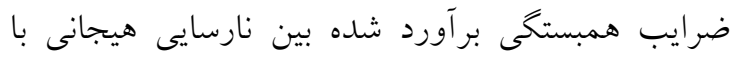

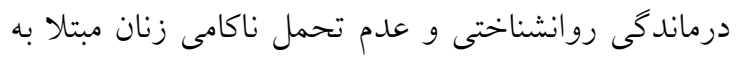

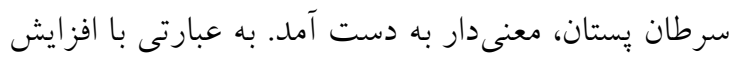

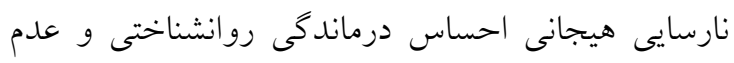

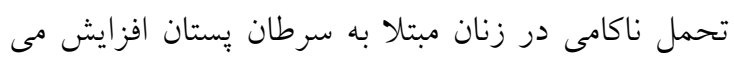
يابد. با توجه به جنبه نوآورى يزوهش و ابنه ابنه، متغيرهاى

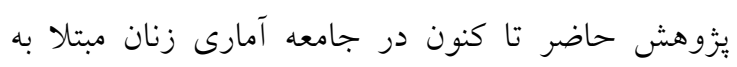

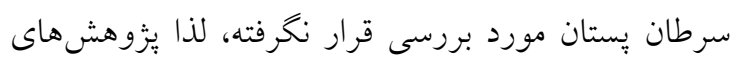

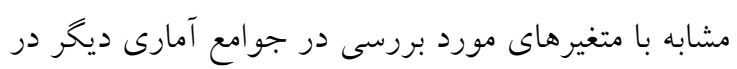
بحث همسويى و ناهمسويى ذكر خواهند شد. اين نتايج

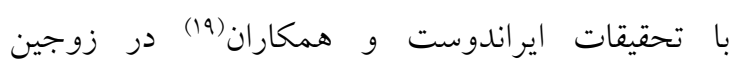


روانشناختى و نارسايى و عدم تعادل در هيجانها هستند و در موقعيتهاى مختلف زندكى نمى توانند از هيجانات

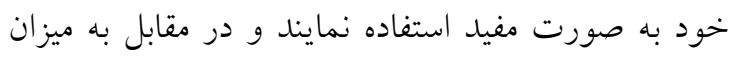

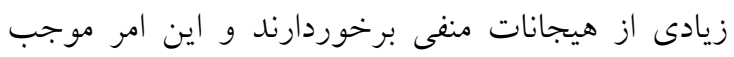

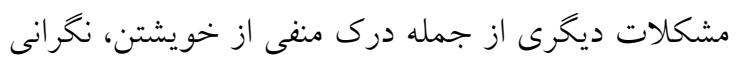

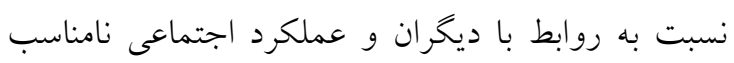

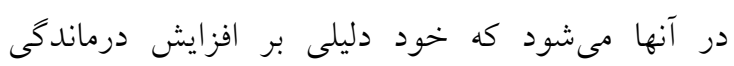
روانشناختى در آنان مىباشد (Tr).

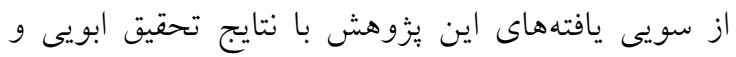

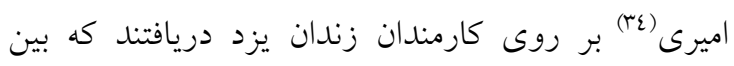

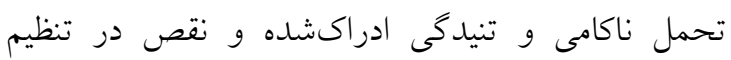
هيجان با افسردگى رابطه وجود دارد و تحمل ناكامى و تنيدگى ادراكشده به ميزان زيادى افسردكى را تبيين

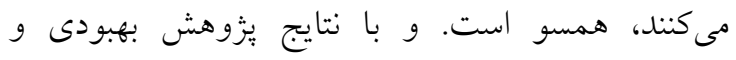

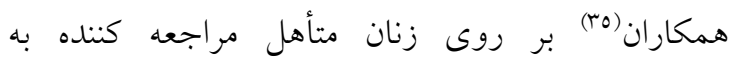

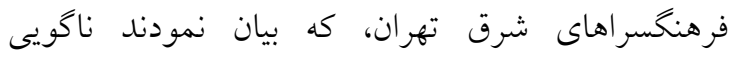

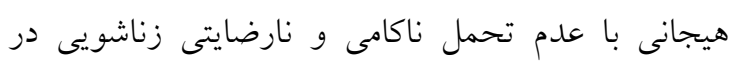

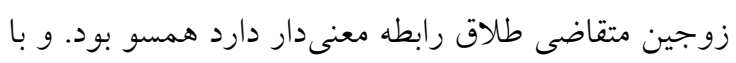

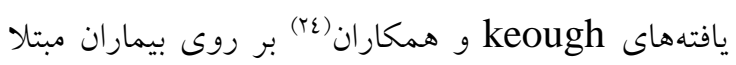

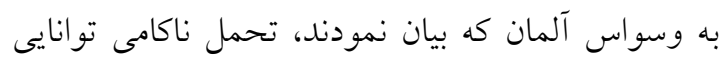

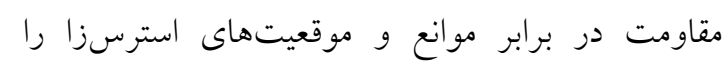

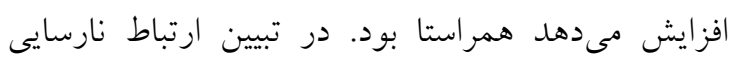

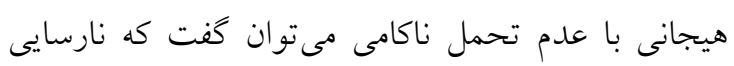

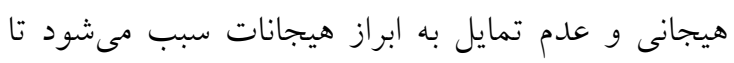

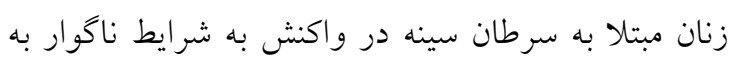
درستى عمل نكرده و در مواجهه با شرايط استرسزا

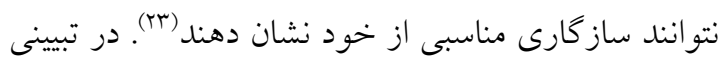

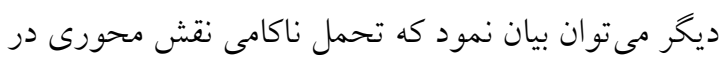

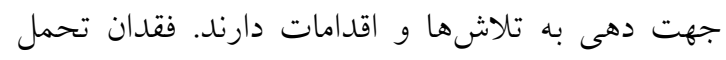

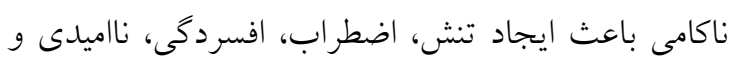

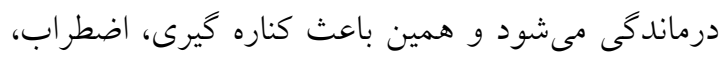

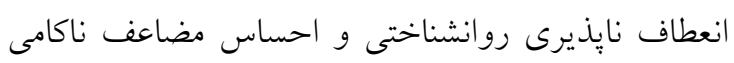

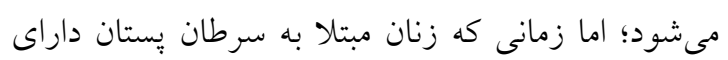

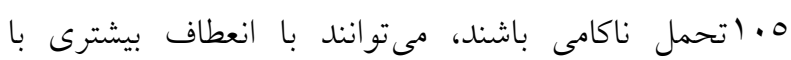

اى از طرحوارههاى مبتنى بر يردازش اطلاعات هستند كه

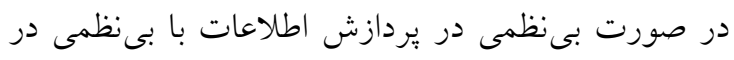

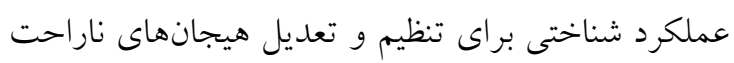

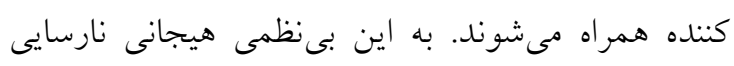

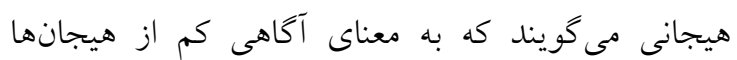

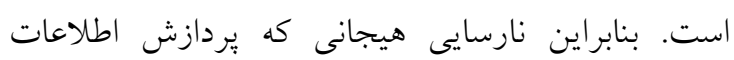

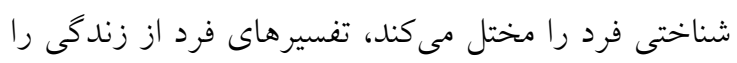
نيز مخدوش مى كند و به دريافت صحيح وى از ميزان

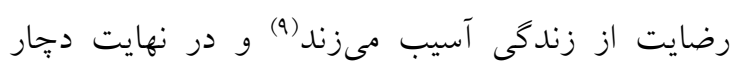

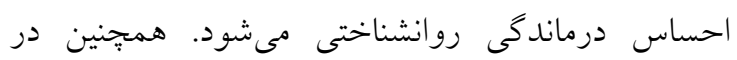

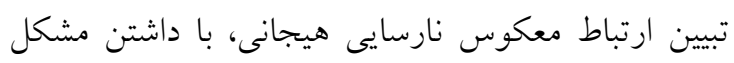

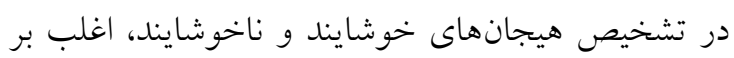

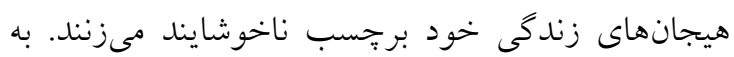

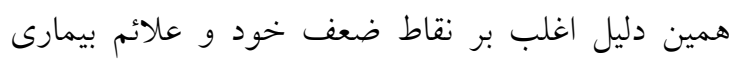
تمركز نموده و احساس نا اميدى و درماندگى را تجريل مى كنند (r)

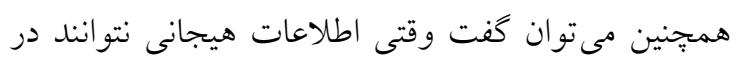

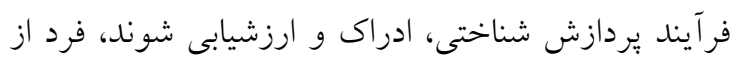

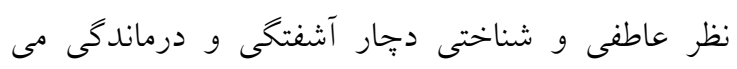

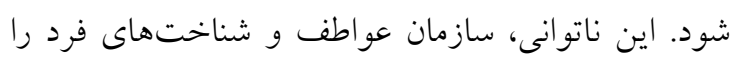

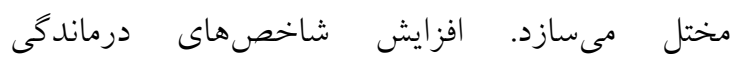

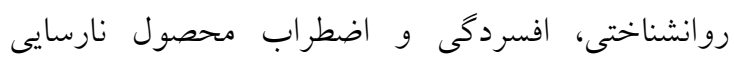
هيجانى محسوب مىشود. تنظيم و مديريت هيجانها نيز

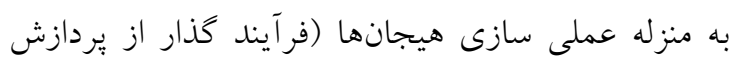
به عمل) در دو سطح رفتارهاى شخصى و تعامل هاى بين

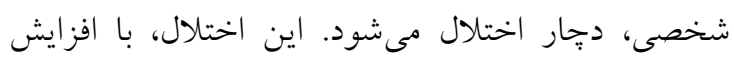

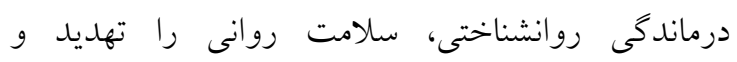
تضعيف مى كند (10). در نارسايى هيجانى، توانايى آشكار

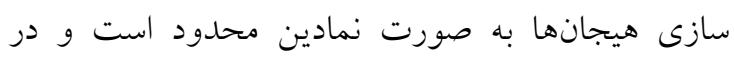

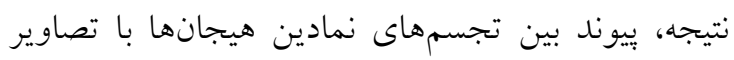
ذهنى و لغات ضعيف مىشود و از نظر شناختى كمتر مهار

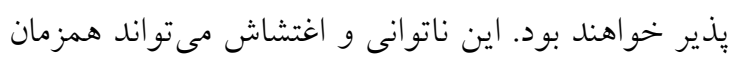
با افزايش درماندگى روانشناختى در ارتباط قرار كيرد (11).

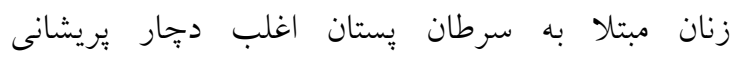




$$
\begin{aligned}
& \text { بنابراين، بيشنهاد مىشود در يزوهشهاى آينده به اين }
\end{aligned}
$$

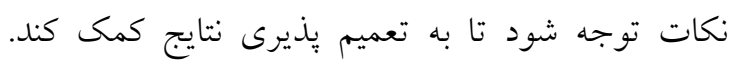

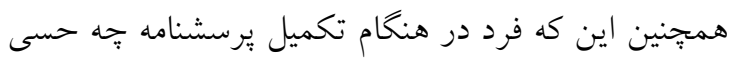

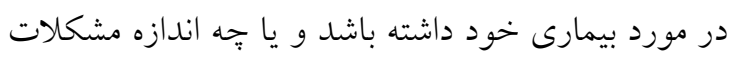

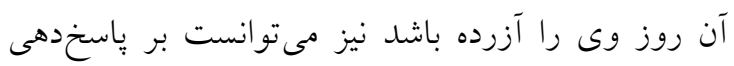

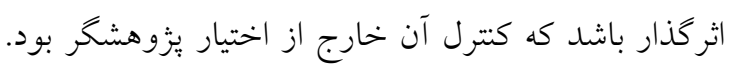

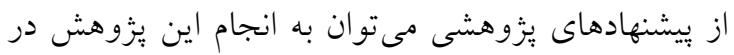

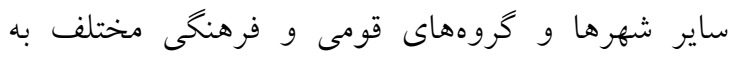

$$
\begin{aligned}
& \text { منظور بررسى بيشتر تعميم نتايج اشاره نمود. و با توجه به به وهنه }
\end{aligned}
$$

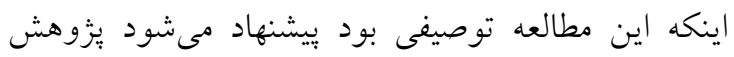

$$
\begin{aligned}
& \text { هاى مداخلهاى در راستاى كاهش اضطراب و بالا بردن } \\
& \text { ميزان تحمل ناكامى و تاب آورى بيماران انجام شود. }
\end{aligned}
$$

تعارض منافع: نويسندكان هيج كونه تعارض منافعى را

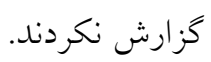

\section{تقدير و تشكر}

اين مقاله نتايج بر كرفته از يايان نامه كارشناسى ارشد در

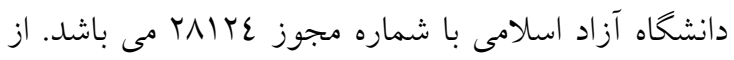

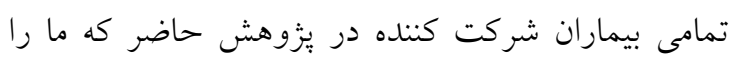

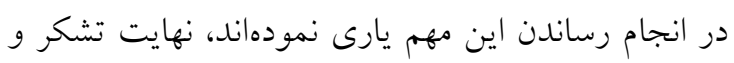

$$
\text { قدردانى را داريم. }
$$

$$
\begin{aligned}
& \text { بيمارى، روند طولانى مدت درمان و مسائل و مشكلات } \\
& \text { زندكى برخورد كنند (rq). } \\
& \text { نتيجه كلى مطالعه نشان داد كه بين نارسايى هيجانى با درد داني }
\end{aligned}
$$

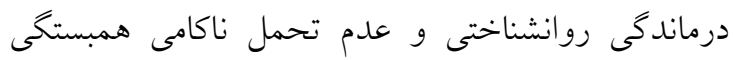

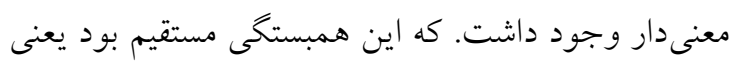

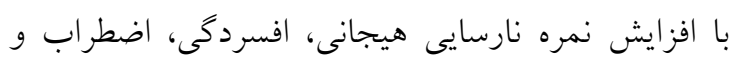

$$
\begin{aligned}
& \text { استرس زنان مبتلا به سرطان يِتان افزايش پيدا مى كرد و } \\
& \text { نارسايى هيجانى با عدم تحمل ناكامى همبستخى مستقيم }
\end{aligned}
$$

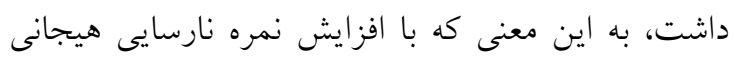

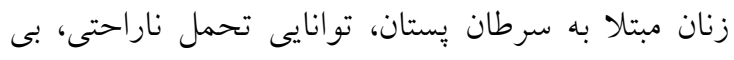

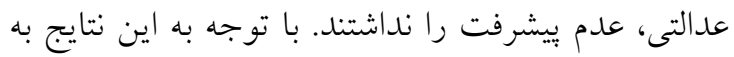

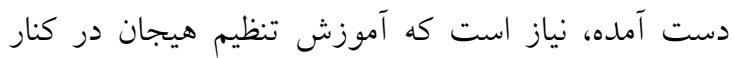

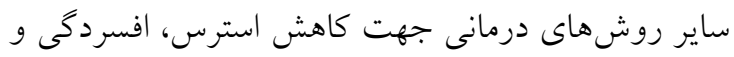

$$
\begin{aligned}
& \text { اضطراب و تاب آورى و تحمل ناكامى زنان مبتلا به } \\
& \text { سرطان يستان مورد استفاده قرار كيرد. يافتهاى اين لمابل }
\end{aligned}
$$

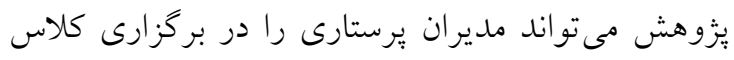

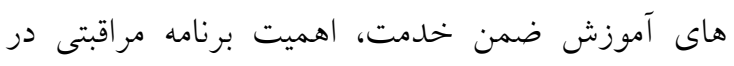

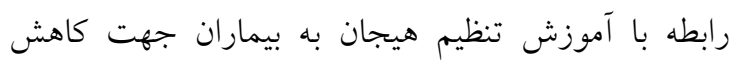

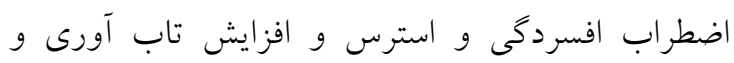

$$
\begin{aligned}
& \text { تحمل ناكامى و كيفيت زندكى كمك نمايد. }
\end{aligned}
$$

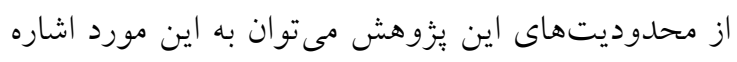

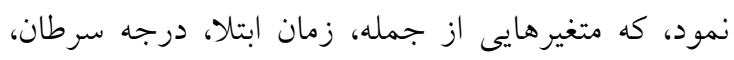

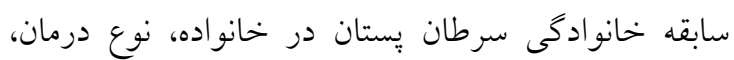

$$
\begin{aligned}
& \text { داشتن عمل جراحى در يزوهش حاضر لحاظ نخرديد، }
\end{aligned}
$$

\section{References}

1. Chen PY, Chang HC. The coping process of patients with cancer European. J Oncol Nurs. 2014;16(3):224-31.

2. Elahi Nejad S, Makvand-Hosseini S, Sabahi P. Effect of Neurofeedback Therapy versus Group Reality Therapy on Anxiety and Depression Symptoms among Women with Breast Cancer: A Clinical Trial Study. Iranian Quarterly Journal of Breast Disease. 2019;11(4):39-52. [Persian]

3. Fallahchai R. Mediating Role of Supportive Dyadic Coping in the Association Between Stress and Marital Adjustment in Women Undergoing Treatment for Breast Cancer. Iranian Quarterly Journal of Breast Disease. 2018;11(3):21-31. [Persian]

4. Lerch MF, Thrane SE. Adolescents with chronic illness and the transition to self-management: A systematic review. J Adolesc. 2019;72:152-61.

5. Khalatbari J, Hemmat i SV, Mohammadi H. Effect of compassion-focused therapy on body image and marital satisfaction in women with breast cancer: A randomized educational trial study. Iranian Journal of Breast Diseases. 2018;11(3):8-20. [Persian] 
6. Mousavi H, Bagherian R. Health literacy and breast cancer. Quarterly Journal of Health Psychology. 2019 22;8(31):91-102. [Persian]

7. O’Neil A, Stevenson CE, Williams ED, Mortimer D, Oldenburg B, Sanderson K. The healthrelated quality of life burden of co-morbid cardiovascular disease and major depressive disorder in Australia: findings from a population-based, cross-sectional study. Quality of life research. 2013;22(1):37-44.

8. Rajandram RK, Ho SM, Samman N, Chan N, McGrath C, Zwahlen RA. Interaction of hope and optimism with anxiety and depression in a specific group of cancer survivors: a preliminary study. BMC research notes. 2011;4(1):1-7.

9. Mahmoodi H, Karbalaee Bagheri Z. Effectiveness of Acceptance and Commitment Therapy on a Sense of Hope and Belief to the Just World in Patients with Breast Cancer. Quarterly Journal of Health Psychology. 2020;9(34):155-70. [Persian]

10. Taylor GJ, Bagby RM. An overview of the alexithymia construct. The handbook of emotional intelli-gence, 2000: 263-76. San Francisco: Jossey-Bass.

11. Sayadpour Z, Akbari M. The Role of Alexithymia and Rumination in Predicting the Life Satisfaction in Obesity Patients: Iranian Psychologists. 2018;15(57):59-69. [Persian]

12. Grabe HJ, Schwahn C, Barnow S, Spitzer C, John U, Freyberger HJ, Schminke U, Felix S, Völzke H. Alexithymia, hypertension, and subclinical atherosclerosis in the general population. $J$ Psychosom Res. 2010;68(2):139-47.

13. Baiardini I, Abbà S, Ballauri M, Vuillermoz G, Braido F. Alexithymia and chronic diseases: the state of the art. G Ital Med Lav Ergon. 2011;33(1 Suppl A):A47-52.

14. Kojima M, Senda Y, Nagaya T, Tokudome S, Furukawa TA. Alexithymia, depression and social support among Japanese workers. Psychotherapy and Psychosomatics. 2003;72(6):307-14.

15. Rahmani Javanmard S, Khani MH. A study and comparison of Alexithymia, Distress tolerance, and Anger rumination among Women with Hypertension and Normal Women. Quarterly Journal of Health Psychology. 2017;6(23):136-50. [Persian]

16. Afsharpour S, Aghdasi A. A comparative study of the effectiveness of reality therapy and existential therapy on the resilience of women with breast cancer. Women and Family Studies. 2020;13(47):25-41. [Persian]

17. Mardanian Dehkordi L, Babashahi M. Evaluation of fatigue and its related factors in cancer patients undergoing chemotherapy. Journal of Health and Care. 2018;20(2):156-64. [Persian]

18. Basharpoor S, Amani S, Narimani M. The effectiveness of Narrative Exposure Therapy on improving posttraumatic symptoms and interpersonal reactivity in patients with cancer. Archives of Rehabilitation. 2019;20(3):230-41. [Persian]

19. Irandoost R, Malihi Al-Zakerini S, Sohrabi Osmord F, Ahi Q. A Causal Model of Sexual Function Based on Sexual Dysfunctional Beliefs, Psychological Distress and Dimensions of Marital Intimacy. The Women and Families Cultural-Educational. 2019;13(45):135-52. [Persian]

20. Yoosefi N, Karimipoor B. Effectiveness of training the Mindfulness-Based Stress Reduction Program (MBSR) on the Self-Efficacy and Frustration Tolerance in Parents of physical-motor disabled children. Psychology of Exceptional Individuals. 2018;8(30):113-32. [Persian]

21. Nolen-Hoeksema S, McBride A, Larson J. Rumination and psychological distress among bereaved partners. J Person Social Psychol. 1997;72(4):855-862.

22. Khezri Moghadam N, Tashk A. The Effectiveness of Parent Management Training (PMT) on Frustration Tolerance and Adjustment of Adolescent Girls. Rooyesh-e-Ravanshenasi Journal (RRJ). 2020;9(8):111-22. [Persian]

23. Domínguez LR, Gámez LC. Corporate reporting on risks: Evidence from Spanish companies. Revista de Contabilidad. 2014;17(2):116-29.

24. Keough ME, Riccardi CJ, Timpano KR, Mitchell MA, Schmidt NB. Anxiety symptomatology: The association with distress tolerance and anxiety sensitivity. Behavior therapy. 2010;41(4):56774.

25. Sharf RS. Theories of psychotherapy \& counseling: Concepts and cases. Cengage Learning; 2015.

26. Besharat MA. Reliability and factorial validity of a Farsi version of the 20-item Toronto Alexithymia Scale with a sample of Iranian students. Psychological reports. 2007;101(1):209-20. [Persian] 
27. Lovibond PF, Lovibond SH. The structure of negative emotional states: Comparison of the Depression Anxiety Stress Scales (DASS) with the Beck Depression and Anxiety Inventories. Behav Res Therapy. 1995;33(3):335-43.

28. Delshad Noughabi A, Ghorbany Moghadam I, Khavasi M, Raznahan R, Abbasi Mendi A, Mohsenikhah M. Evaluation of depression, anxiety and stress in hemodialysis patients in Gonabad city 2017. The Horizon of Medical Sciences. 2019;25(2):138-4. [Persian]

29. Harrington N. The frustration discomfort scale: Development and psychometric properties. Clinical Psychology \& Psychotherapy: An International Journal of Theory \& Practice. 2005;12(5):374-87.

30. Mahmoudpour A, Dehghanpour S, Vazifedan F. The prediction of distress tolerance based on attachment styles, frustration tolerance and religious attitude in divorced women. Rooyesh-eRavanshenasi Journal (RRJ). 2020;9(4):93-102. [Persian]

31. Derakhtkar A, Safikhani A. Relationship between social support and coping strategy and frustration tolerance in students of Shiraz University. Rooyesh-e-Ravanshenasi Journal (RRJ). 2019;8(10):125-32. [Persian]

32. Besharat M, Zamani Froshani N, Moafi A. The mediating role of cognitive emotion regulation strategies on the relationship between personality characteristics and psychological distress in siblings of children with cancer. Journal of psychologicalscience. 2017;16(62):179-97. [Persian]

33. Noli G, Cornicelli M, Marinari GM, Carlini F, Scopinaro N, Adami GF. Alexithymia and eating behaviour in severely obese patients. J Human Nutr Dietet. 2010;23(6):616-9.

34. Abooie B, Amiri M. Relationship between Perceived Stress, Frustration Tolerance, Cognitive Emotion Regulation with Depression Syndrome. Middle East J Disabili Stud. 2019;9:79. [Persian]

35. Behboudi M, Rostami R, Janghoo E. The role of ethical foundations and tolerance of failure in predicting marital adjustment of married women. Rooyesh-e-Ravanshenasi Journal (RRJ). 2020;9(10):17-26. [Persian] 